\title{
THE EVOLUTIONARY HISTORY OF PARTHENOGENETIC CNEMIDOPHORUS LEMNISCATUS (SAURIA: TEIIDAE).

\author{
II. MATERNAL ORIGIN AND AGE INFERRED FROM \\ MITOCHONDRIAL DNA ANALYSES
}

\author{
D. K. Vyas, ${ }^{1}$ C. Moritz, ${ }^{1.4}$ D. Peccinini-Seale, ${ }^{2}$ J. W. Wright, ${ }^{3}$ and W. M. Brown ${ }^{1}$ \\ 'Laboratory of Molecular Systematics, Museum of Zoology and Department of Biology, \\ University of Michigan, Ann Arbor, MI 48109-1048, USA \\ ${ }^{2}$ Departamento de Biologia, Instituto de Biociencias, Universidade de Sao Paulo, 05499, \\ Sao Paulo, BRAZIL \\ ${ }^{3}$ Herpetology Section, Museum of Natural History, 900 Exposition Boulevard, \\ Los Angeles, CA 90007, USA
}

\begin{abstract}
Restriction endonuclease analyses were performed on mitochondrial DNAs (mtDNAs) representing unisexual parthenogenetic (cytotypes A, B, and C) and bisexual (cytotypes D and E) populations of Amazonian lizards presently regarded as Cnemidophorus lemniscatus. The results of mtDNA cleavage map comparisons among these $C$. lemniscatus indicated that (1) there was no cleavage site variation among the unisexuals, (2) mtDNAs from the bisexual cytotypes D and $\mathrm{E}$ differed in sequence from one another by about $13 \%$, and (3) mtDNAs from cytotypes A-C differed from those of cytotype $D$ by about $5 \%$ and from those of cytotype $E$ by about $13 \%$. Higher resolution restriction fragment size comparisons confirmed the high degree of similarity among the unisexual mtDNAs, but identified 12 cleavage site variants among the 13 cytotype $\mathrm{D}$ mtDNAs examined.

Both cladistic and phenetic (UPGMA) analyses of the data indicate that the unisexual and cytotype $D$ mtDNAs form a single clade, suggesting that a female of cytotype $D$ was the maternal progenitor of the unisexuals. The similarity among the unisexual mtDNAs and the variability among those of cytotype $D$ suggest that the three unisexual cytotypes arose recently from a common maternal lineage. The mtDNA variability observed among cytotype D individuals has a strong geographic component, suggesting that the unisexuals arose from one or a few geographically proximal populations. The mtDNA comparisons also support the conclusion, based on allozyme comparisons (Sites et al., 1990, this issue), that cytotypes D and E, although presently allocated to C. lemniscatus, are separate species.
\end{abstract}

Received January 10, 1989. Accepted October 1, 1989.

One-third of the approximately 50 species in the lizard genus Cnemidophorus consist exclusively of parthenogenetically reproducing females. Comparative studies of morphology, ecology, chromosomes, and allozymes among these and their bisexual congeners have demonstrated that the unisexuals originated by interspecific hybridization (reviewed by Cole, 1975; Wright, 1978; Darevsky et al., 1985; Dessauer and Cole, 1989). Mitochondrial DNA (mtDNA) analyses (Brown and Wright, 1979; Wright et al., 1983; Densmore et al., 1985, 1989a, $1989 b$; Moritz et al., 1989a, 1989b) have extended and strengthened this correlation and have provided data that exclude the possibility, proposed by Cuellar (1974, 1977, 1987) and by Darevsky et al. (1985), that certain of the triploid unisexuals could have

\footnotetext{
${ }^{4}$ Present address: Department of Zoology, University of Queensland, St. Lucia QLD 4067, Australia.
}

been derived from spontaneously arisen parthenogenetic diploids.

Prior to the current study (see also Sites et al., 1990), only one possible exception to the correlation between hybridity and parthenogenesis in Cnemidophorus remained. This was C. lemniscatus, a species found from northern Central America to the Amazon Basin of Brazil and on nearby islands (Serena, 1984, 1985). As presently defined, the $C$. lemniscatus complex contains both normally reproducing bisexual and parthenogenetically reproducing unisexual populations. In Brazil, C. lemniscatus is distributed along the Amazon river and its tributaries, with unisexual and bisexual populations having nonoverlapping distributions in the eastern and western parts of this range, respectively (see Fig. 1 in Sites et al., 1990).

Combined analysis of multiple data sets can provide detailed information on the 
TABLE 1. Species, reproductive modes, cytotypes, and collecting localities for lizards whose mtDNAs were surveyed. ${ }^{a}$

\begin{tabular}{|c|c|c|c|c|c|}
\hline No. & Species & Mode & Cytotype & Locality & $N$ \\
\hline 1. & C. lemniscatus & $\mathbf{P}$ & A & Belem, Brazil & 6 \\
\hline 2. & C. lemniscatus & $\mathbf{P}$ & B & Oriximina, Brazil & 20 \\
\hline 3. & C. lemniscatus & $\mathbf{P}$ & $\mathrm{C}$ & Maruda, Barzil & 8 \\
\hline 4. & C. lemniscatus & $\mathbf{P}$ & $\mathrm{C}$ & Capanema, Brazil & 11 \\
\hline 5. & C. lemniscatus & B & $\mathrm{D}$ & Alter do Chao, Brazil & 10 \\
\hline 6. & C. lemniscatus & B & $\bar{D}$ & Boa Vista, Brazil & 3 \\
\hline 7. & C. lemniscatus & $\mathbf{B}$ & $\mathrm{E}$ & Urucurituba, Brazil & 3 \\
\hline 8. & C. lemniscatus & $\mathbf{B}$ & $\mathrm{E}$ & Manacapuru, Brazil & 3 \\
\hline 9. & C. arubensis & $\mathbf{B}$ & - & Aruba, Neth. Antilles & \\
\hline 10. & C. murinus & B & - & Curacao, Neth. Antilles & \\
\hline 11. & C. nigricolor & B & - & Isla Orchila, Venezuela & \\
\hline 12. & A. ameiva & $\mathbf{B}$ & - & Alter do Chao, Brazil ${ }^{b}$ & \\
\hline 13. & A. ameiva & B & - & Manacapuru, Brazil ${ }^{b}$ & \\
\hline 14. & A, auberi & B & - & Andros Island, Bahamas & \\
\hline
\end{tabular}

${ }^{a}$ C. lemniscatus cytotypes A-E correspond to the designations of Peccinini-Seale and Frota-Pessoa (1974). Mode refers to bisexual (B) or parthenogenetic $(P)$ reproduction. One mtDNA from each locality was analyzed with 14 enzymes cleaving at 5 - or 6 -bp sites; $N$ corresponds to the number of mtDNAs analyzed with enzymes cleaving at 4-bp sites. Locality numbers correspond to those in Figure 1 of Sites et al. (1990). For further specimen and locality information, see the Appendix.

${ }_{A}$. ameiva localities 12 and 13 are, respectively, the same as $C$. lemniscatus localities 5 and 8 .

evolutionary history of unisexual taxa (Moritz et al., 1989b; Vrijenhoek, 1989). The companion paper on allozyme variation (Sites et al., 1990) provides evidence that the Amazonian unisexuals are hybrids between cytotype D and cytotype $\mathrm{E}$ bisexuals and that the latter are two distinct species. These conclusions are also well supported by chromosomal data (see Fig. 7 of Peccinini-Seale and Frota-Pessoa, 1974; Peccinini-Seale, 1989; Sites et al., 1990).

Analysis of mtDNA, a maternally transmitted (Dawid and Blackler, 1972; reviewed in Avise, 1986) and rapidly evolving molecule (Brown et al., 1979; reviewed in Brown, 1985) can provide unique insights into the history of unisexual taxa (Brown and Wright, 1979; reviewed in Moritz et al., $1987,1989 \mathrm{~b}$ ). Specifically, comparisons of mtDNAs from bisexual and unisexual $C$. lemniscatus can be used to address the following questions: (1) Are the maternal ancestors of the three cytologically distinct unisexual forms (A, B, and C) closely related? (2) Did the unisexuals arise independently at geographically widespread localities or at one site with subsequent range expansion? (3) Are the unisexuals of recent or ancient origin? (4) How similar are the mtDNAs from the bisexual cytotypes D and E? (5) Can either of the bisexual taxa be identified as the source of the female parent of the unisexuals?

\section{MATERIALS AND MethodS \\ DNA Preparation and Analysis}

Mitochondrial DNA was prepared from field collected lizards (Table 1; Appendix) and analyzed using methods described previously (Brown, 1980; Wright et al., 1983; Densmore et al., 1985). Most of the lizards collected in 1987 were also karyotyped and examined by allozyme electrophoresis (Sites et al., 1990). DNA fragment sizes were determined by electrophoresis through agarose and polyacrylamide gels, using restriction endonuclease-digested $\phi \times 174 \mathrm{RF}$ DNA and $\lambda$ phage DNA as size standards.

\section{Statistical Analyses}

Sequence divergence between mtDNAs was estimated from (1) cleavage site changes inferred from the fragment patterns produced by endonucleases that cleave at 4-base pair (bp) sites and (2) comparisons of cleavage maps for 5-bp and 6-bp sites, using the equations of Nei and Tajima (1983) and a program described in Nei et al. (1985). This program was also used to cluster the mtDNAs according to their sequence divergence estimates by the UPGMA. Character states (presence/absence of cleavage sites) were analyzed using the Wagner parsimony algorithm in PAUP (version 2.4.0; Swofford, 1985). 


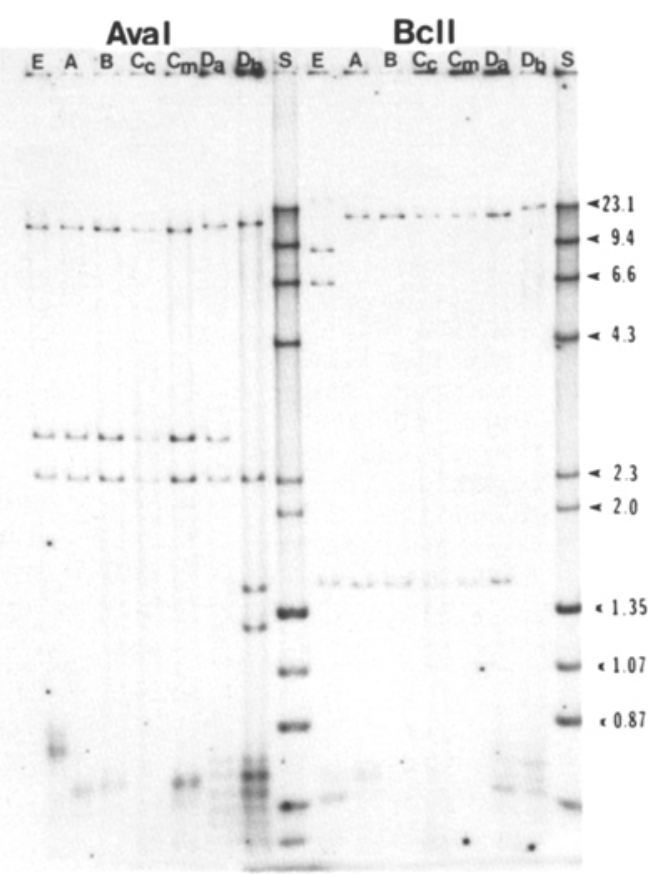

Fig. 1. Autoradiograph of a $1 \%$ agarose gel after electrophoretic separation of fragments produced by $A v a I$ or $B c l$ I digestion of C. lemniscatus mtDNAs. Correspondence of gel lane to cytotype and locality: $\mathrm{E}=$ E, Manacapuru; $A=A$, Belem; $B=B$, Oriximina; $C_{c}$ $=\mathrm{C}$, Capanema; $\mathrm{C}_{\mathrm{m}}=\mathrm{C}$, Maruda; $\mathrm{D}_{\mathrm{a}}=\mathrm{D}$, Alter do Chao; $\mathrm{D}_{\mathrm{b}}=\mathrm{D}$, Boa Vista. $\mathrm{S}=$ size standard: HindIIIdigested $\lambda$ phage DNA and HaeIII-digested $\phi$ X 174 RFDNA. Numbers are DNA fragment sizes, in $\mathbf{k b}$.

\section{RESULTS}

Variation among Unisexual

Cnemidophorus lemniscatus

Four mtDNAs, representing four widely separated populations and each of the unisexual cytotypes $A, B$, and C (Table 1), were

FIG. 2. Autoradiographs of $1.2 \%$ agarose (A) and $3.5 \%$ polyacrylamide (B) gels after electrophoretic separation of fragments produced by $H i n f \mathrm{I}, \mathrm{HinPI}$, or $\mathrm{Mbo \textrm {I }}$ digestion of $C$. lemniscatus mtDNAs. Correspondence of gel lane to cytotype and locality: $A=A$, Belem; $B$ $=\mathrm{B}$, Oriximina; $\mathrm{C}=\mathrm{C}$, Capanema; $\mathrm{D}_{\mathrm{a}}=\mathrm{D}$, Alter do Chao; $D_{b}=D$, Boa Vista. $S=$ size standards: for $A, \lambda$ phage DNA digested with $A v a \mathrm{I}$ plus $B g I \mathrm{II}$; for B, HaeIIIdigested $\phi \mathrm{X} 174 \mathrm{RF}-\mathrm{DNA}$; fragment sizes are in $\mathrm{kb}$. Asterisks $\left(^{*}\right)$ mark fragments that arise from the HinfI and $H$ in PI cleavage site differences among the unisexual mtDNAs (see text). The faint bands present in some lanes (e.g., HinPI digests, lane A) are due to incomplete digestion.
A $\begin{gathered}\text { Hinfl } \\ D_{a} D_{b} C \text { B A }\end{gathered}$
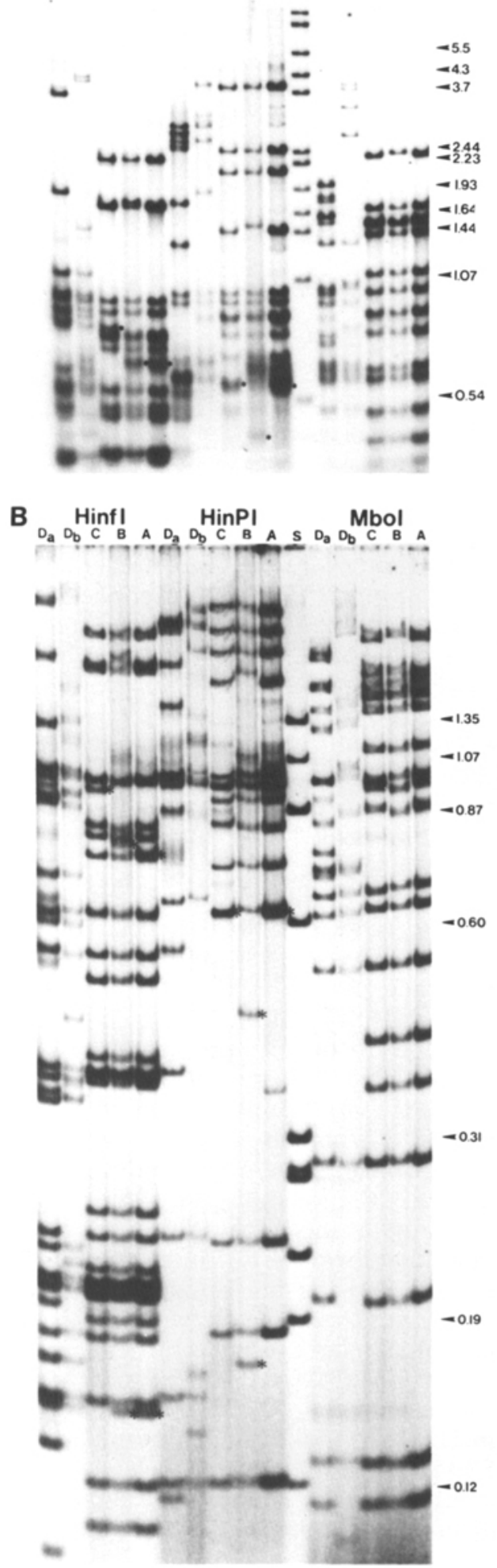


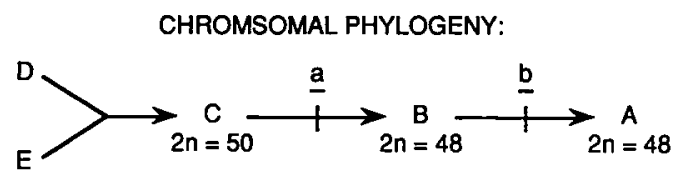

HYPOTHESIS I:

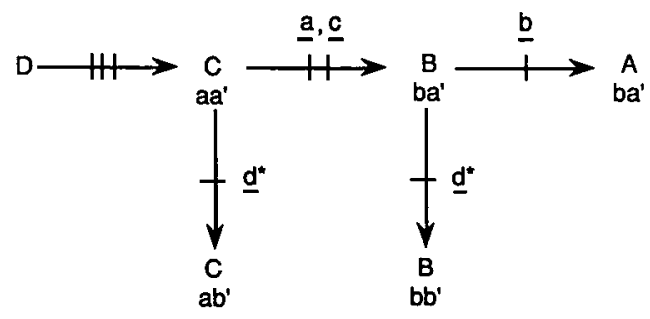

HYPOTHESIS 11 :

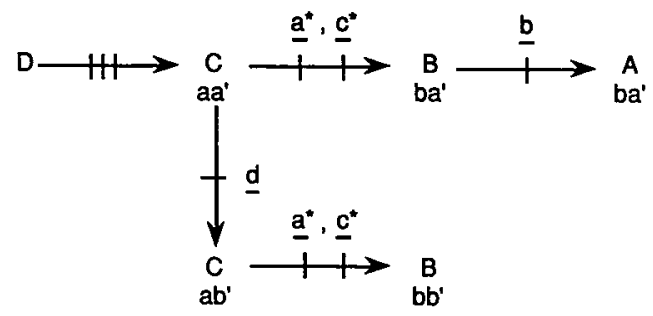

FIG. 3. Two hypotheses explaining mtDNA cleavage type distributions among the chromosomal forms of unisexual $C$. lemniscatus, based on the chromosomal phylogeny originally proposed by J. Wright (see Fig. 7 of Peccinini-Seale and Frota-Pessoa, 1974). Hypothesis I requires convergent gains $\left(d^{*}\right)$ of HinPI sites in cytotype $B$ and $C$ individuals. Hypothesis II requires multiple origin of cytotype $B$ individuals via parallel chromosome losses $\left(a^{*}\right)$ as well as convergent gains $\left(c^{*}\right)$ of Hinfl sites. Upper case letters designate cytotypes; lower case letters not underlined designate mtDNA cleavage types. Character changes: a, loss of one chromosome pair; $b$, pericentric inversion in the second pair of chromosomes; c, gain of Hinfl site (a $\rightarrow$ b) in mtDNA; d, gain of $\bar{H}$ inPI site $\left(\mathrm{a}^{\prime} \rightarrow \mathrm{b}^{\prime}\right)$ in mtDNA.

compared by digestion with each of 14 restriction endonucleases that cut at 5- or 6-bp sites (listed in Fig. 4, legend). No variation in fragment size was observed (e.g., Fig. 1), indicating complete conservation of the 32 sites cleaved by these enzymes. At this level of resolution there was no evidence for length variation among these mtDNAs. The estimated size of the mtDNA in the unisexuals is approximately $16.7 \mathrm{kilo-}$ bases (kb).

For a higher resolution analysis, mtDNAs of 45 unisexuals (Table 1) were digested with the endonucleases $H$ infI, Hin PI, DdeI, MboI, MspI, and TagI. These enzymes cleaved a total of 180 4-bp sites per mtDNA. The HinfI digests fell into two groups that differed by one cleavage site (Fig. 2); mtDNAs from cytotypes $\mathbf{A}$ and $\mathbf{B}$ had unique fragments of 0.87 and $0.14 \mathrm{~kb}$, whereas those from cytotype $\mathrm{C}$ had instead a unique $1.03 \mathrm{~kb}$ fragment. The HinPI digests also identified two groups that differed by one cleavage site (Fig. 2), but these were not congruent with the HinfI groups. mtDNAs having the additional HinPI site [all C (Maruda) and some B (Oriximina) mtDNAs] had one $0.625 \mathrm{~kb}$ fragment plus unique fragments of 0.45 and $0.164 \mathrm{~kb}$, whereas those without it [all $\mathrm{A}$, all $\mathrm{C}(\mathrm{Ca}-$ panema), and the remaining $B$ (Oriximina) mtDNAs] had two fragments of $0.625 \mathrm{~kb}$ instead. No cleavage site variation was observed in digests with the other enzymes (e.g., $M b o \mathrm{I}$; Fig. 2).

The Hinfl and HinPI data define four mtDNA types whose sequences are estimated to differ by $0.07-0.14 \%$ (mean among the four $=0.09 \%$ ). The derivation of these is considered in the context of the chromosomal data, which suggest that cytotypes $A$ and $B$ are derived sequentially from cytotype C (Fig. 3; Sites et al., 1990; also see Fig. 7 of Peccinini-Seale and Frota-Pessoa, 1974). The Hinfl site separating the 0.87 and $0.14 \mathrm{~kb}$ fragments probably arose in the ancestor of cytotype B. The distribution of the HinPI variants among the cytotypes is more complex. The presence of both HinPI variants in cytotypes $B$ and $C$ could indicate either independent site gains in both cytotype $\mathrm{B}$ and $\mathrm{C}$ individuals (Hypothesis I; Fig. 3) or multiple origins of cytotype B from cytotype $\mathrm{C}$ unisexuals (Hypothesis II; Fig. $3)$. Hypothesis $I$ is the more parsimonious. It requires only the convergent gain of HinPI sites, whereas Hypothesis II requires parallel chromosomal changes as well.

Only minor size variation (i.e., $\leq 400 \mathrm{bp}$ ) was observed among the unisexual mtDNAs. This is illustrated in Figure 2 by the lowered mobility of the second largest HinfI, the fourth largest HinPI, and the largest $M b o I$ fragments in lanes B compared to those in lanes A and C. However, despite the examples in Figure 2, this variation does not partition among cytotypes or localities 


\section{A. amoiva, Alter do Chao}

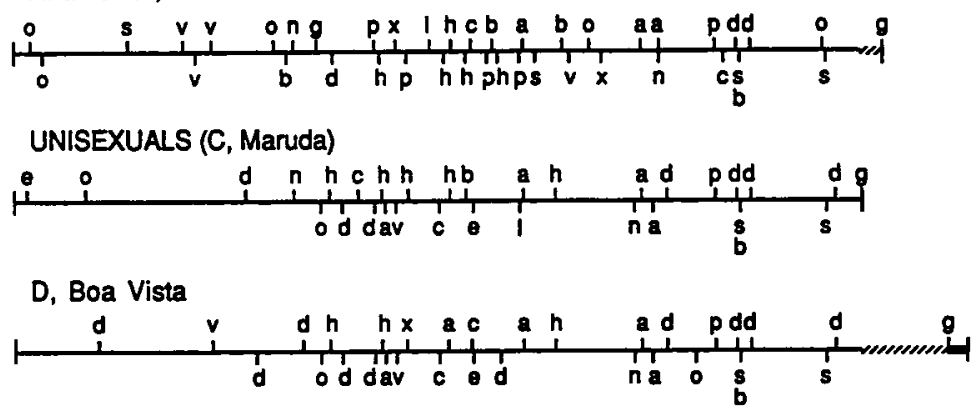

D, Alter do Chao

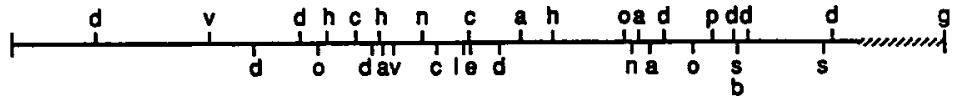

\section{E, Manacapuru}

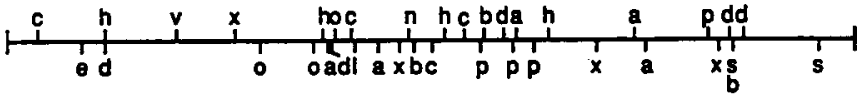

\section{E, Unueurituba}
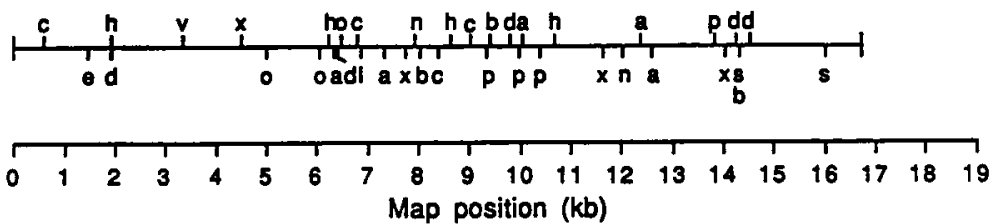

FIG. 4. Restriction endonuclease cleavage maps of $C$. lemniscatus and $A$. ameiva mtDNAs. The scale at the bottom indicates distance, in $\mathbf{k b}$, and was used to define the map positions in Table 3 . All maps were linearized and aligned using the highly conserved BamHI/SstII sites at position 14.3, in agreement with other studies of Cnemidophorus mtDNA. Slashes indicate regions with length variation among mtDNAs from $C$. lemniscatus and $A$. ameiva. The heavy line in the D, Boa Vista, mtDNA map denotes the position of a 400 bp length difference between the two D mtDNAs. Enzyme abbreviations: a, $A v a \mathrm{I} ; \mathrm{b}, B a m \mathrm{HI}$; c, $B c l \mathrm{I} ; \mathrm{d}, S p e \mathrm{I}$; e, EcoRI; g, BglII; h, HindIII; l, SalI; n, NheI; o, NcoI; p, PvuII; s, SstII; v, EcoRV; x, XbaI.

of unisexual $C$. lemniscatus. The observation of minor length variation is a common feature of inter- and intrapopulational mtDNA comparisons of Cnemidophorus (Densmore et al., 1985, 1989a, 1989b; Moritz et al., 1989a) and other vertebrate species (reviewed by Brown, 1985, and by Moritz et al., 1987), and the nature and possible causes of this kind of variation have been characterized and discussed. In the present study, no further characterization or analysis of this size variation was undertaken.

\section{Variation among Bisexual \\ Cnemidophorus lemniscatus}

Four mtDNAs from individuals representing four bisexual populations of Amazonian C. lemniscatus (localities 5-8, Table
1) were examined using 14 enzymes that cleave at 5 - and 6-bp sites (listed in the legend to Fig. 4). The two cytotype $E$ mtDNAs had 38 (Urucurituba) and 39 (Manacapuru) cleavage sites, differing by only one NheI site. More variation was observed between the two cytotype $\mathrm{D}$ mtDNAs. These had 35 (Alter do Chao) and 32 (Boa Vista) cleavage sites and differed by single cleavage sites for $A v a \mathrm{I}, B c l \mathrm{I}, N c o \mathrm{I}$, NheI, SalI, and SpeI (Table 2). The AvaI and $B c l$ I differences are apparent between lanes $D_{a}$ and $D_{b}$ in Figure 1. Estimates of sequence divergence are $0.2 \pm 0.2 \%$ between the two cytotype $\mathrm{E}$ mtDNAs and 1.9 $\pm 0.8 \%$ between the two cytotype $\mathrm{D}$ mtDNAs.

The mtDNAs also differed in size; both E mtDNAs were $16.7 \mathrm{~kb}$, whereas the D 
TABLE 2. Estimates of pairwise sequence divergence among Cnemidophorus lemniscatus and Ameiva ameiva mitochondrial DNAs. ${ }^{a}$

\begin{tabular}{|c|c|c|c|c|c|c|}
\hline mtDNA & AM-ATCH & UNI & D-BV & D-ATCH & E-MAN & E-URU \\
\hline AM-ATCH & 42 & $\begin{array}{r}18.8 \\
\pm 3.6\end{array}$ & $\begin{array}{r}18.8 \\
\pm 3.6\end{array}$ & $\begin{array}{r}19.0 \\
+3.6\end{array}$ & $\begin{array}{r}16.3 \\
\pm 3.1\end{array}$ & $\begin{array}{r}16.6 \\
\pm 3.1\end{array}$ \\
\hline UNI & 12 & 32 & $\begin{array}{r}5.5 \\
\pm 1.5\end{array}$ & $\begin{array}{r}5.7 \\
+1.5\end{array}$ & $\begin{array}{r}13.0 \\
\pm 2.7\end{array}$ & $\begin{array}{r}13.3 \\
\pm 2.7\end{array}$ \\
\hline D-BV & 12 & 23 & 32 & $\begin{array}{r}1.9 \\
+0.8\end{array}$ & $\begin{array}{r}13.0 \\
\pm 2.7\end{array}$ & $\begin{array}{r}13.3 \\
\pm 2.7\end{array}$ \\
\hline D-ATCH & 12 & 23 & 29 & 35 & $\begin{array}{r}13.3 \\
+2.7\end{array}$ & $\begin{array}{r}13.5 \\
\pm 2.7\end{array}$ \\
\hline E-MAN & 15 & 16 & 16 & 16 & 38 & $\begin{array}{r}0.2 \\
\pm 0.2\end{array}$ \\
\hline E-URU & 15 & 16 & 16 & 16 & 38 & 39 \\
\hline
\end{tabular}

$a$ The estimates of percentage divergence \pm 1 standard error are above, the number of cleavage sites compared is on, and the number of cleavage sites shared is below the diagonal. Abbreviations: D-ATCH and D-BV, cytotype D from Alter do Chao and Boa Vista: E-URU and E-MAN, cytotype E from Urucurituba and Manacapuru; UNI, cytotypes A, B, and C from the four unisexual localities listed in Table 1; AM-ATCH, Ameiva ameiva from Alter do Chao.

mtDNAs were 18.4 and $18.8 \mathrm{~kb}$. The length differences typically appeared in the largest fragment of a digest (e.g., Fig. 1), and 1.7 $\mathrm{kb}$ of the difference between the $E$ and $D$ mtDNAs mapped to the region between the conserved SpeI site at map position 16.2 and the $B g l \mathrm{II}$ site to its right (Fig. 4). Side by side comparisons of combined $S p e I$ and $B g l \mathrm{II}$ digests revealed a $0.5 \mathrm{~kb} S p e \mathrm{I} / B g l \mathrm{II}$ fragment in the $\mathrm{E}$ mtDNAs and a corresponding $2.2 \mathrm{~kb}$ fragment in the $\mathrm{D} \mathrm{mt}-$ DNAs. The $400 \mathrm{bp}$ difference between the two cytotype $\mathrm{D}$ mtDNAs mapped to the region between the $B g l$ II site at map position 18.4 and the SpeI site at position 1.6, as indicated in Figure 4.

A higher resolution comparison of mtDNAs within cytotypes $D$ and $E$, using enzymes that cleave at 4-bp sites, was consistent with the above cleavage map comparisons. Cytotype D mtDNAs were heterogeneous. Thirteen ( 3 from Boa Vista and 10 from Alter do Chao) were digested with each of 7 enzymes (MboI, Hinfl, HinPI, DdeI, MspI, RsaI, and TaqI), which cleaved an average of 194 sites per mtDNA. The fragment size comparisons revealed 12 cleavage types among the 13 mtDNAs; cleavage site differences ranged from none with any enzyme, between the most similar pair (from Alter do Chao), to several with each enzyme, between mtDNAs from Alter do Chao and Boa Vista (Fig. 1). Although cleavage site variation was observed between individuals and among groups of in- dividuals within each locality, the degree of divergence was less than between mtDNAs from different localities. In contrast, digests of six cytotype E mtDNAs (three each from Urucurituba and Manacapuru) with $\mathrm{MboI}$, $H$ infI, $H$ in PI, and $D d e \mathrm{I}$ revealed no variation at any of 111 cleavage sites, indicating that the $0.2 \%$ sequence difference estimate based on the cleavage map comparisons may be an overestimate.

\section{Comparisons with Ameiva and Other Cnemidophorus}

A mtDNA representing the $A$. ameiva population at Alter do Chao was mapped and compared to C. lemniscatus mtDNAs, from which it differs at numerous sites (Fig. 4). Its size was approximately $17.2 \mathrm{~kb}$, with the difference relative to $C$. lemniscatus mtDNA mapping to the same region between the conserved Sst II and BglII sites (Fig. 4) as was the size difference between mtDNAs of C. lemniscatus cytotypes $\mathrm{D}$ and E. Fragment patterns of mtDNAs from additional species ( $C$. murinus, $C$. nigricolor, C. arubensis, $A$. auberi) and populations ( $A$. ameiva from Manacapuru) were characterized (data not shown), but their cleavage sites were not mapped. Comparisons of the fragment patterns yielded by these mtDNAs revealed few similarities to either $C$. lemniscatus or to each other. These results are in qualitative agreement with those yielded by comparisons of allozymes from these same lizards (Sites et al., 1990). 


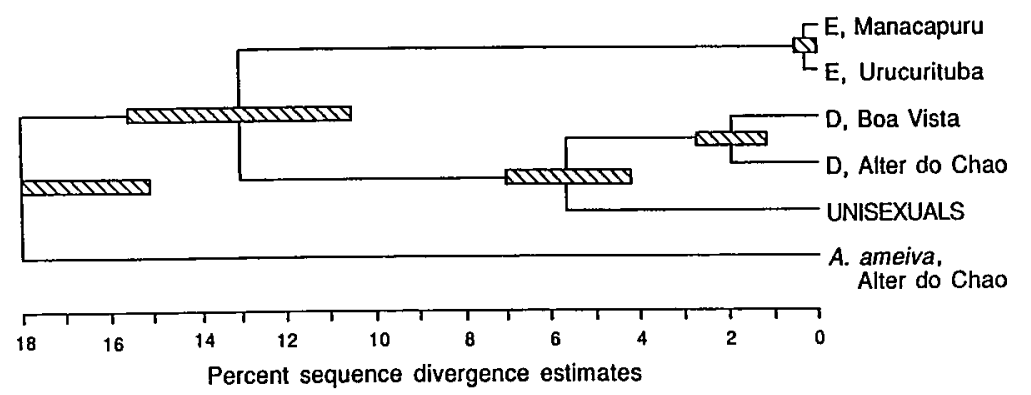

FIG. 5. Dendrogram produced from UPGMA clustering of the mtDNA sequence divergence estimates presented in Table 2. Slashed bars represent standard errors of the estimates. D, E, and UNISEXUALS refer to $C$. lemniscatus cytotypes $\mathrm{D}, \mathrm{E}$, and $\mathrm{A}-\mathrm{C}$, respectively.

\section{Phylogenetic Relationships}

Estimates of sequence divergence between the six mapped mtDNAs (Table 2) and clustering based on these estimates (Fig. 5) indicate that the mtDNAs of the unisexuals are most similar to those from cytotype $D$ bisexuals. Although the mtDNAs of A, $B$, and $C$ unisexuals differed from those of cytotype $\mathrm{D}$ bisexuals by $5-6 \%$, they differed from cytotype $E$ mtDNAs by $13 \%$, which is approximately the amount by which $\mathrm{D}$ and E mtDNAs differed from each other. Ameiva ameiva mtDNA was the most distinct, its average pairwise difference from the $C$. lemniscatus mtDNAs being approximately $18 \%$.

A more rigorous estimate of relationships was based on parsimony analysis of informative cleavage sites, i.e., those with states (presence/absence) shared by two or more (but not by all) of the mtDNAs. The maximum parsimony cladogram was rooted using $A$. ameiva as the outgroup. Analysis of 40 informative characters (Table 3), using exhaustive branch swapping, yielded a single shortest tree with 45 steps and a consis- tency index of 0.89 (excluding $A$. ameiva; Fig. 6). This analysis, like that using UPGMA, indicated that the mtDNAs of the unisexuals were most closely related to mtDNAs of cytotype D bisexuals.

\section{Discussion \\ Maternal Ancestry}

The phylogenetic analyses demonstrate that mtDNAs of the unisexuals (cytotypes, A, B, and C) are most closely related to those of cytotype D bisexuals. However, the actual cytotype D female(s) involved in the hybridization event(s) presumably came from a locality other than those examined, given the considerable ( $>5 \%$ ) divergence of these D mtDNAs from those of the unisexuals. The substantial difference among mtDNAs from different cytotype D populations supports this suggestion. Further sampling of populations from the Amazon basin and areas to the north will be needed to provide more information about the geographic origin of the unisexual C. lemniscatus.

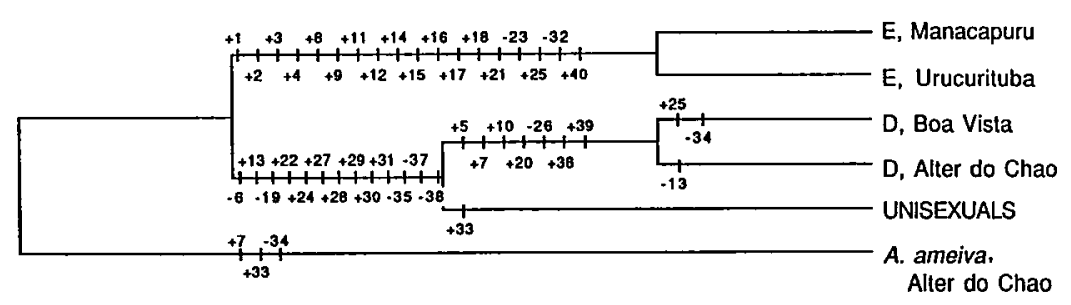

FIG. 6. Maximum-parsimony cladogram showing the distribution of character states. The data employed are numbered and coded in Table 3. D, E, and UNISEXUALS refer to C. lemniscatus cytotypes D, E, and A$\mathrm{C}$, respectively. 
TABLE 3. Summary of phylogenetically informative cleavage sites. ${ }^{a}$

\begin{tabular}{|c|c|c|c|c|c|c|c|c|}
\hline \multirow[b]{2}{*}{ No. } & \multirow[b]{2}{*}{ Site } & \multirow[b]{2}{*}{ Map position } & \multicolumn{6}{|c|}{ Mitochondrial DNAs and characters } \\
\hline & & & AM-ATCH & UNI & $\overline{\mathrm{D}-\mathrm{BV}}$ & D-ATCH & E-MAN & E-URU \\
\hline 1. & c & 0.6 & 0 & 0 & 0 & 0 & 1 & 1 \\
\hline 2. & $\mathrm{e}$ & 1.45 & 0 & 0 & 0 & 0 & 1 & 1 \\
\hline 3. & h & 1.9 & 0 & 0 & 0 & 0 & 1 & 1 \\
\hline 4. & d & 1.9 & 0 & 0 & 0 & 0 & 1 & 1 \\
\hline 5. & d & 2.65 & 0 & 0 & 1 & 1 & 0 & 0 \\
\hline 6. & $\mathrm{v}$ & 3.35 & 1 & 0 & 0 & 0 & 1 & 1 \\
\hline 7. & $\mathrm{v}$ & 3.9 & 1 & 0 & 1 & 1 & 0 & 0 \\
\hline 8. & $\mathrm{x}$ & 4.5 & 0 & 0 & 0 & 0 & 1 & 1 \\
\hline 9. & 0 & 5.0 & 0 & 0 & 0 & 0 & 1 & 1 \\
\hline 10. & d & 5.75 & 0 & 0 & 1 & 1 & 0 & 0 \\
\hline 11. & $\mathrm{a}$ & 6.3 & 0 & 0 & 0 & 0 & 1 & 1 \\
\hline 12. & d & 6.35 & 0 & 0 & 0 & 0 & 1 & 1 \\
\hline 13. & d & 6.5 & 0 & 1 & 1 & 0 & 0 & 0 \\
\hline 14. & o & 6.5 & 0 & 0 & 0 & 0 & 1 & 1 \\
\hline 15. & 1 & 6.85 & 0 & 0 & 0 & 0 & 1 & 1 \\
\hline 16. & $\mathrm{n}$ & 7.95 & 0 & 0 & 0 & 0 & 1 & i \\
\hline 17. & $\mathrm{~b}$ & 8.0 & 0 & 0 & 0 & 0 & 1 & 1 \\
\hline 18. & $\mathrm{p}$ & 10.4 & 0 & 0 & 0 & 0 & 1 & 1 \\
\hline 19. & $\mathbf{x}$ & 11.6 & 1 & 0 & 0 & 0 & 1 & 1 \\
\hline 20. & 0 & 13.45 & 0 & 0 & 1 & 1 & 0 & 0 \\
\hline 21. & $\mathbf{x}$ & 14.05 & 0 & 0 & 0 & 0 & 1 & 1 \\
\hline 22. & d & 7.1 & 0 & 1 & 1 & I & 0 & 0 \\
\hline 23. & $\mathrm{~h}$ & 7.2 & 1 & 1 & 1 & 1 & 0 & 0 \\
\hline 24. & $\mathrm{v}$ & 7.5 & 0 & 1 & 1 & 1 & 0 & 0 \\
\hline 25 . & $\mathbf{x}$ & 7.7 & 0 & 0 & 1 & 0 & 1 & 1 \\
\hline 26. & $\mathrm{~h}$ & 8.6 & 1 & 1 & 0 & 0 & 1 & 1 \\
\hline 27. & $\mathrm{e}$ & 9.05 & 0 & 1 & 1 & 1 & 0 & 0 \\
\hline 28. & 1 & 10.0 & 0 & 1 & 1 & 1 & 0 & 0 \\
\hline 29. & $\mathrm{n}$ & 12.25 & 0 & 1 & 1 & 1 & 0 & 0 \\
\hline 30. & d & 12.9 & 0 & 1 & 1 & 1 & 0 & 0 \\
\hline 31. & d & 16.2 & 0 & 1 & 1 & 1 & 0 & 0 \\
\hline 32. & $\mathrm{~g}$ & 16.7 & 1 & 1 & 1 & 1 & 0 & 0 \\
\hline 33. & $\mathrm{n}$ & 5.5 & 1 & 1 & 0 & 0 & 0 & 0 \\
\hline 34. & $\mathrm{c}$ & 6.8 & 0 & 1 & 0 & 1 & 1 & 1 \\
\hline 35. & $\mathrm{p}$ & 9.35 & 1 & 0 & 0 & 0 & 1 & 1 \\
\hline 36. & d & 4.8 & 0 & 0 & 1 & 1 & 0 & 0 \\
\hline 37. & $\mathrm{~b}$ & 9.4 & 1 & 0 & 0 & 0 & 1 & 1 \\
\hline 38. & $\mathrm{p}$ & 10.0 & 1 & 0 & 0 & 0 & 1 & 1 \\
\hline 39. & d & 9.6 & 0 & 0 & 1 & 1 & 0 & 0 \\
\hline 40. & $\mathrm{~d}$ & 9.8 & 0 & 0 & 0 & 0 & 1 & 1 \\
\hline
\end{tabular}

a Abbreviations for species and localitics as in Table 2, and for endonucleases as in the legend to Figure 5. Character numbers correspond to those on the cladogram in Figure 7. Character coding: 0, cleavage site absent; 1 , cleavage site present. Map positions (in kb) correspond to those in Figure 5.

\section{Origin and Age of Unisexual}

C. lemniscatus

The extremely low level of mtDNA variation among the unisexuals suggests that they arose from hybridization(s) involving only one or a few closely related females. Also, given the extent of sequence difference between cytotype $\mathrm{D}$ mtDNAs from different localities, it seems likely that the unisexuals arose in a geographically restricted area. Finally, because of the rapid rate of mtDNA evolution among vertebrates (Brown et al., 1979; reviewed by Brown, 1985; Moritz et al., 1987), the mtDNA homogeneity within the unisexuals implies that these lineages are of recent origin.

The above conclusions echo those already drawn for other unisexual Cnemidophorus (Brown and Wright, 1979; Wright et al., 1983; Densmore et al., 1989a, 1989b; Moritz et al., 1989a), for unisexual gekkos in the Heteronotia binoei complex (Moritz et al., $1989 b$ and unpubl. data), and for the unisexual fish Menidia clarkhubbsi (Echelle et al., 1989). That all of these unisexuals seem to have originated recently supports the hypothesis that the evolutionary dura- 
TABLE 4. Sequence divergence estimates for mtDNAs from bisexual species of Cnemidophorus involved in hybrid origins of unisexual lineages.

\begin{tabular}{llrc}
\hline \hline \multicolumn{1}{c}{ Unisexual } & \multicolumn{1}{c}{ Hybridizing bisexuals } & $\%^{a}$ & Reference \\
\hline C. lemniscatus & C. lemniscatus cytotypes $\mathrm{D} \times \mathrm{E}$ & 13 & This study \\
C. cozumela & C. angusticeps $\times$ C. deppei & 15 & $b$ \\
C. sp. G ${ }^{C}$ & C. motaguae $\times$ C. guttatus & 15 & $b$ \\
C. tesselatus & C. marmoratus $\times$ C. septemvittatus & 9 & $b$ \\
C. neomexicanus & C. marmoratus $\times$ C. inornatus & 12 & $b$ \\
C. laredoensis & C. gularis $\times$ C. sexlineatus & 5 & $d$ \\
\hline
\end{tabular}

a Percentage sequence difference between the miDNAs of the bisexual species

$b$ C. Moritz, J. Wright, V. Singh, and W. Brown (submitted).

${ }^{c}$ Undescribed species; J. W. Wright (unpubl. data).

$d$ Wright et al. (1983).

tion of parthenogenetic vertebrate taxa is short (Williams, 1975; Maynard-Smith, 1978; White, 1978; Bell, 1982; Michod and Levin, 1988).

The proposed recent origin of unisexual C. lemniscatus from a small geographic area has two important implications for interpreting their biogeographic history. First, because the unisexuals are of hybrid origin (Sites et al., 1990), they must have arisen in the region where the bisexual parent taxa are or were in contact, presumably near their present western boundary. The rapid spread of the unisexuals from west to east, presumably by rafting, would be facilitated by their parthenogenesis. It is, therefore, difficult to reconcile the current distributions (see Fig. 1 in Sites et al., 1990) with the east to west migration proposed by Vanzolini (1970). Second, the apparent geographic restrictions on the origin(s) of the unisexuals conflict with suggestions that they stem from multiple, geographically widespread and independent events (Vanzolini, 1970, 1978; Hoogmoed, 1973 p. 272; Peccinini-Seale and Frota-Pessoa, 1974), although analysis of Venezuelan and Suriname specimens is needed to test the generality of this result. In particular, it seems unlikely that the unisexual population at Obidos arose separately (Vanzolini, 1970); a more plausible explanation for the shift in sex ratio that he reported is that the bisexual population was invaded and replaced by a unisexual one.

\section{Are Cytotypes D and E Different Species?}

Allozyme data (Sites et al., 1990) indicate strongly that the $\mathrm{D}$ and $\mathrm{E}$ chromosome forms of bisexual $C$. lemniscatus are different species; the genetic distance between $\mathrm{D}$ and
E, based on allozymes, is 20 times greater than that between D populations that are separated by a similar geographic distance. The mtDNA comparisons support and strengthen this observation. The estimated sequence divergence between mtDNAs from the $\mathrm{D}$ and $\mathrm{E}$ cytotypes, $13 \%$, is more than six times greater than that between geographically separated samples of the D cytotype (Table 2), and is also greater than that separating the mtDNAs of many other bisexual species of Cnemidophorus, including some that have hybridized to produce unisexual lineages (Table 4). The empirical evidence that cytotypes $D$ and $E$ are separate species makes the correlation between hybridity and parthenogenesis in Cnemidophorus absolute, and precludes further use of $C$. lemniscatus as support for the argument that parthenogenesis arose spontaneously in Cnemidophorus.

\section{ACKNOWLEDGMENTS}

We wish to thank T. Dowling for helpful suggestions and assistance throughout this study; W. E. Magnuusson, W. Hoeh, L. Vawter, M. Hall, D. Smith, and K. Blakely for technical comments and/or assistance; V. Singh and S. Singh for excellent laboratory assistance; L. Garcia and P. Litz for field assistance; J. Schall for providing specimens from Aruba; and M. Van Bolt and D. Bay for artwork and photography. D.PS. thanks T. C. d'Avila Pires of the Museu Paraense Emilio Goeldi, and W. E. Magnuusson and C. Morato of the Instituto Nacional de Pesquisas da Amazonia for their support during collecting trips in Brazil. This study was supported, in part, by grants from 
the National Science Foundation and the National Institutes of Health, U.S.A., and from the Fundacão de Amparao à Pesquisa do Estado de São Paulo and the Conselho Nacional de Pesquisas, Brazil.

\section{Literature Cited}

Avise, J. D. 1986. Mitochondrial DNA and the evolutionary genetics of higher animals. Phil. Trans. R. Soc. London B312:325-342.

BeLl, G. 1982. The Masterpiece of Nature. CroomHelm, London, Canberra.

Brown, W. M. 1980. Polymorphism in mitochondrial DNA of humans as revealed by restriction endonuclease analysis. Proc. Natl. Acad. Sci. U.S.A. 77:3605-3609.

- 1985. The mitochondrial genome of animals, pp. 95-130. In R. MacIntrye (ed.), Molecular Evolutionary Genetics. Plenum Press, N.Y.

Brown, W. M., AND J. W. Wright. 1979. Mitochondrial DNA analyses and the origin and relative age of parthenogenetic lizards (genus Cnemidophorus). Science 203:1247-1249.

Brown, W. M., M. George, JR., AND A. C. Wilson. 1979. Rapid evolution of animal mitochondrial DNA. Proc. Natl. Acad. Sci. U.S.A. 76:1967-1971.

COLE, C. J. 1975. Evolution of parthenogenetic species of reptiles, pp. 340-355. In R. Reinboth (ed.), Intersexuality in the Animal Kingdom. Springer-Verlag, N.Y.

CuEllar, O. 1974. On the origin of parthenogenesis in vertebrates: The cytogenetic factors. Am. Natur. 108:625-648.

1977. Animal parthenogenesis. Science 197: $837-843$.

- 1987. The evolution of parthenogenesis: Historical perspective, pp. 43-104. In P. B. Moens (ed.), Meiosis. Academic Press, N.Y.

DarevSky, I. S., L. A. KuPRIYANOVA, AND T. UZzell. 1985. Parthenogenesis in reptiles, pp. 412-526. In C. Gans and F. Billet (eds.), Biology of the Reptilia. Wiley, N.Y.

DAwid, I. B., AND A. W. Blackier. 1972. Maternal and cytoplasmic inheritance of mtDNA in Xenopus. Dev. Biol. 29:139-151.

Densmore, L. D., J. W. Wright, AND W. M. Brown. 1985. Length variation and heteroplasmy are frequent in mitochondrial DNA from parthenogenetic and bisexual lizards (genus Cnemidophorus). Genetics 110:689-707.

Densmore, L. D., C. Moritz, J. W. Wright, and W. M. BRown. 1989a.. Mitochondrial DNA analyses and the origin and relative age of parthenogenetic lizards (genus Cnemidophorus). IV. Nine sexlineatus group unisexuals. Evolution 43:969-983.

DenSmORE, L. D., J. W. WRIGHT, AND W. M. Brown. $1989 b$. . Mitochondrial DNA analyses and the origin and relative age of parthenogenetic lizards (genus Cnemidophorus). III. C. neomexicanus and the tesselatus complex. Evolution 43:943-957.

Dessauer, H. C., AND C. J. Cole. 1989. Diversity between and within nominal forms of unisexual teiid lizards, pp. 49-70. In R. Dawley and J. Bogart (eds.), Evolution and Ecology of Unisexual Vertebrates. New York State Museum, Albany, NY.

Echelle, A. A., Dowling, T. E., Moritz, C., AND Brown, W. M. 1989. Mitochondrial DNA diversity and the origin of the Menidia clarkhubbsi complex of unisexual fishes (Atherinidae). Evolution 43:984-993.

Hoogmoed, M. S. 1973. Notes on the herpetofauna of Surinam. IV. The lizards and amphisbaenians of Surinam. W. Junk, The Hague.

MAYNARD-SMith, J. 1978. The Evolution of Sex. Cambridge University Press, Cambridge, MA.

Michod, R. E., AND B. R. Levin (eds.). 1988. The Evolution of Sex. Sinauer, Sunderland, MA.

Moritz, C., T. E. Dowling, AND W. M. BrowN. 1987. Evolution of animal mitochondrial DNA; Relevance for population biology and systematics. Annu. Rev. Ecol. Syst. 18:269-293.

Moritz, C., J. W. Wright, AND W. M. BROwN. 1989a. Mitochondrial DNA analyses and the origin and relative age of parthenogenetic lizards (genus Cnemidophorus). III. C. velox and $C$. exsanguis. Evolution 43:958-968.

Moritz, C., W. M. Brown, L. D. Densmore, J. W. Wright, D. Vyas, S. Donellan, M. Adams, and P. BAVERSTOCK. 1989 . Genetic diversity and the dynamics of hybrid parthenogenesis in Cnemidophorus (Teiidae) and Heteronotia (Gekkonidae), pp. 87-1 12. In R. Dawley and J. Bogart (eds.), Evolution and Ecology of Unisexual Vertebrates. New York State Museum, Albany, NY.

NeI, M., AND F. TAJIMA. 1983. Maximum likelihood estimation of the number of nucleotide substitutions from restriction site data. Genetics 105:207217.

Nei, M., J. C. Stephens, AND N. Saitou. 1985. Methods for computing the standard errors of branching points in an evolutionary tree and their application to molecular data from humans and apes. Mol. Biol. Evol. 2:66-85.

Peccinint-Seale, D. 1989. Genetic studies on the bisexual and unisexual populations of Amazonian Cnemidophorus, pp. 241-251. In R. Dawley and J. Bogart (eds.), Evolution and Ecology of Unisexual Vertebrates. New York State Museum, Albany, NY. Peccinini-Seale, D., and D. Frota-Pessoa. 1974. Structural heterozygosity in parthenogenetic populations of Cnemidophorus lemniscatus (Sauria, Teiidae) from the Amazonas valley. Chromosoma 47:439-451.

Schultz, R. J. 1977. Evolution and ecology of unisexual fishes. Evol. Biol. 10:277-331.

Serena, M. 1984. Distribution and habits of parthenogenetic and sexual Cnemidophorus lemniscatus (Sauria, Teiidae) in Surinam. Copeia 3:713-719.

- 1985. Zoogeography of parthenogenetic whiptail lizards (Cnemidophorus lemniscatus) in the Guianas: Evidence from skin graft, karyotypes and erythrocyte areas. J. Biogeog. 121:49-58.

Sites, J., D. Peccinini-Seale, C. Moritz, J. W. Wright, AND W. M. BROWN. 1990. The evolutionary history of parthenogenetic Cnemidophorus lemniscatus (Sauria, Teiidae). I. Evidence for a hybrid origin. Evolution 44:906-921.

SwoFFoRD, D. L. 1985. Phylogenetic Analysis Using 
Parsimony. User's Manual. Illinois Natural History Survey, Champaign, IL.

Vanzolini, P. E. 1970. Unisexual Cnemidophorus lemniscatus in the Amazonas valley: A preliminary note (Sauria, Teiidae). Pap. Avulsos Zool. 23:6368. 1152.

VRIJENHOEK, R. C. 1989. Genetic and ecological constraints on the origins and establishment of unisexual vertebrates, pp. 24-31. In R. Dawley and J. Bogart (eds.), Evolution and Ecology of Unisexual Vertebrates. New York State Museum, Albany, NY.

White, M. J. D. 1978. Modes of Speciation. Freeman, San Francisco.

Williams, G. C. 1975. Sex and Evolution. Monogr. Population. Biol., No. 8. Princeton University Press, Princeton, N.J.

WRIGHT, J. W. 1978. Parthenogenetic lizards. Science 201:1152-1154.

WRIGHT, J. W., C. SPOLSKY, AND W. M. BROWN. 1983. The origin of the parthenogenetic lizard Cnemidophorus laredoensis inferred from mitochondrial DNA analysis. Herpetologica 39:410-416.

Corresponding Editor: R. C. Vrijenhoek

\section{APPENDIX}

All Cnemidophorus used in these analyses have been deposited as voucher specimens in the herpetological collections of the University of Michigan Museum of
Zoology (UMMZ), the Museu Paraense Emilio Goeldi (MPEG), Sao Paulo, Brazil, the University of California Museum of Vertebrate Zoology (UCMVZ), and the Natural History Museum of Los Angeles County (LACM). Abbreviated locality data and catalog numbers are provided below. More complete specimen data are available on request.

Specimens examined: Ameiva ameiva-Alter do Chao, Para, Brazil (UMMZ 183890*); Manacapuru, Amazonas, Brazil (UMMZ 184304). Ameiva auberiBahamas, Andros Island, Small Hope Bay (UMMZ 183964). Cnemidophorus lemniscatus, cytotype ABelem, Para, Brazil (LACM 131706, 131707,*1317089; UCMVZ 192236, 192238). C. lemniscatus, cytotype B-Oriximina, Para, Brazil (MPEG 14652, 14653,* 14654-56; UMMZ 183871-74, 183876-82, 184292 , 184294; LACM 131710-11). C. lemniscatus, cytotype C-Capanema, Para, Brazil (MPEG 14639-42, 14643,* 14666-69; UMMZ 184291); Maruda, Para, Brazil (MPEG 14660,* 14661-64; UMMZ 184298-300). $C$. lemniscatus, cytotype D-Alter do Chao, Para, Brazil (MPEG 14657-58, 14659,* 14665, 14671-72; UMMZ 184296); Boa Vista, Roraima, Brazil (MPEG 14650,* 14651, 14670). C. lemniscatus, cytotype E-Urucurituba, Para, Brazil (LACM 134773,* 134775-77); Manacapuru, Amazonas, Brazil (MPEG 14645,* 1464647; UMMZ 183883). C. arubensis - Netherlands Antilles, Aruba (LACM 131254). C. murinus-Netherlands Antilles, Curacao (LACM 138125). C. nigricolor-Venezuela, Isla Blanquilla (LACM 138126). *Samples used for cleavage mapping; note that some of these were not used in the 4-bp site analyses. 